\title{
Nanostructured W-Cu Electrical Contact Materials Processed by Hot Isostatic Pressing
}

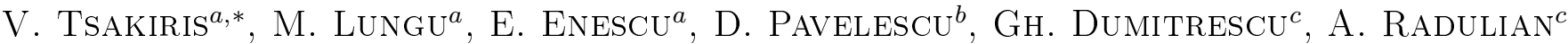
AND N. MocIOI ${ }^{c}$

${ }^{a}$ National Institute for Research and Development in Electrical Engineering ICPE-CA

Splaiul Unirii no. 313, 030138 Bucharest-3, Romania

${ }^{b}$ POLITEHNICA University of Bucharest (UPB), Splaiul Independentei no. 313, 060042, Bucharest-6, Romania

${ }^{c}$ Icpe SA, Splaiul Unirii no. 313, 030138 Bucharest-3, Romania

\begin{abstract}
Nanostructured $\mathrm{W}-\mathrm{Cu}-\mathrm{Ni}$ electrical contact materials to be used in low voltage vacuum switching contactors for nominal currents up to $630 \mathrm{~A}$ were developed successfully by hot isostatic pressing. W-Cu-Ni composite powder mixtures with copper content of 20 to $40 \mathrm{wt} \%$ and $1 \mathrm{wt} \%$ Ni were mechanically alloyed in Ar atmosphere by high-energy ball milling with a ratio of milling steel balls: powders mixtures of 8:1 and rotation speed of $400 \mathrm{rpm}$ for 10 and $20 \mathrm{~h}$. The effect of mechanical alloying on the sintering response of composite compacts was investigated. Also, the sintered contacts were characterized from the point of view of physical, microstructural, mechanical, and functional properties. The nanostructured electrical contacts presented very good sinterability and homogeneous structures with a maximum compactity degree of about $89 \%$. The best $\mathrm{W}-\mathrm{Cu}-\mathrm{Ni}$ compositions with relative density of about $80 \%$, chopping currents lower than $5 \mathrm{~A}$, copper content lower than $40 \%$ as $\mathrm{W}-20 \mathrm{Cu}-1 \mathrm{Ni}(10 \mathrm{~h}$ of mechanical alloying and $20 \mathrm{~h}$ of mechanical alloying) and $\mathrm{W}-30 \% \mathrm{Cu}-\mathrm{Ni}(10 \mathrm{~h}$ of mechanical alloying) were selected to be used in vacuum contactors.
\end{abstract}

DOI: $10.12693 /$ APhysPolA.125.348

PACS: 81.05.Ni, 81.05.Mh, 79.60.Jv, 81.20.Ev

\section{Introduction}

In the past years, $\mathrm{W}-\mathrm{Cu}$ composites have been widely used in automotive, electrical, and military industry in applications such as heat sinks in high power microelectronic devices, electrical contacts in vacuum switching devices such as circuit breakers, contactors and for arcing resistant electrodes and deviator plates in fusion reactors. This wide range of applications is due to a unique combination of the high electrical and thermal conductivities of copper, and the low coefficient of thermal expansion, high hardness, high melting point, low vapor pressure, and high arc erosion resistance of tungsten [1-5].

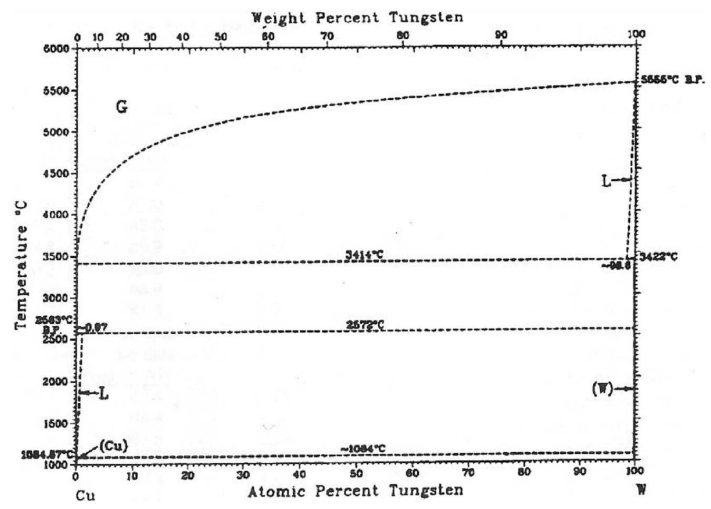

Fig. 1. W-Cu phase diagram at $1 \mathrm{~atm}$.

*corresponding author; e-mail: violeta.tsakiris@icpe-ca.ro
It is well known that $\mathrm{W}$ and $\mathrm{Cu}$ are completely immiscible in both solid and liquid phases according to the equilibrium phase diagram [6] (Fig. 1).

Consequently, the alloying of the two metals proves to be difficult. Because of a large disparity between their melting points and densities and high wetting angle of liquid copper on tungsten, the full-density $\mathrm{W}-\mathrm{Cu}$ alloys cannot be developed by using conventional alloying techniques such as metal-casting processes and are currently manufactured through powder metallurgy techniques $[1,3]$. Mechanical alloying (MA) is an attractive process because of its simplicity, ability to scale up to produce large quantities of powders and is used to increase the sinterability of the $\mathrm{W}-\mathrm{Cu}$ system. This high-energy ball milling method produces high energy impacts on powders by collision between powder particles and grinding media leading to nanocomposite powders with good sinterability $[7,8]$. To activate sintering and reduce sintering temperature of tungsten from $2800{ }^{\circ} \mathrm{C}$ to $1400^{\circ} \mathrm{C}$, the addition of small amounts of the transition metals, such as $\mathrm{Ni}, \mathrm{Fe}, \mathrm{Co}$ or $\mathrm{Pd}$ is practiced [5, 9, 10].

There are a variety of powder consolidation techniques such as hot extrusion, hot isostatic pressing, plasma activated sintering, shock wave consolidation which can be used to maintain the nanocrystalline structure and to achieve near full density $[11,12]$.

The synthesis of $\mathrm{W}-\mathrm{Cu}-\mathrm{Ni}$ powder composites by MA followed by hot isostatic pressing (HIP) is examined. The effect of the milling time (10 to $20 \mathrm{~h}$ ) and composition (20 to $40 \mathrm{wt} \% \mathrm{Cu}, 1 \mathrm{wt} \% \mathrm{Ni}$, and balance $\mathrm{W}$ ) on the obtained electrical contacts and physical, microstructural, mechanical, and functional properties has been investigated. 


\section{Experimental procedure}

The raw materials used to synthesize the nanocrystalline $\mathrm{W}-\mathrm{Cu}-\mathrm{Ni}$ composite powders by $\mathrm{MA}$ technique were tungsten powder $(99.9 \%,<32 \mu \mathrm{m})$ with polygonal morphology (Fig. 2), copper powder $(99.9 \%,<32 \mu \mathrm{m})$ with dendritical morphology (Fig. 3), and nickel powder $(99.9 \%,<32 \mu \mathrm{m})$ (Fig. 4).

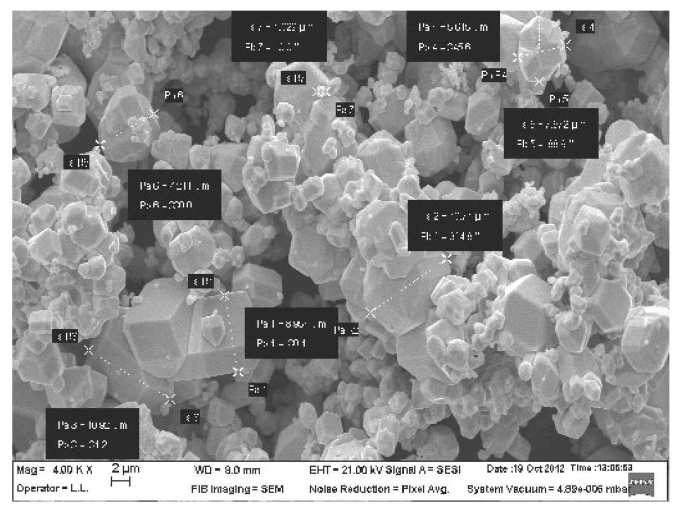

Fig. 2. SEM micrographs of the raw $\mathrm{W}$ powder.



Fig. 3. SEM micrographs of the raw $\mathrm{Cu}$ powder.



Fig. 4. SEM micrographs of the raw Ni powder.

Mixtures containing 20, 30, and $40 \mathrm{wt} \% \mathrm{Cu}$ and $1 \mathrm{wt} \% \mathrm{Ni}$ as sintering aid were MA-ed in a high energy ball mill using stainless steel container and balls with the ball-to-powder weight ratio of 8:1. Argon gas was passed into the container to prevent the oxidation of powder during the milling process. Each powder composition was subjected to the milling process for $10 \mathrm{~h}$ and $20 \mathrm{~h}$ at $400 \mathrm{rpm}$ rotational speed. The powders were mixed with $1.5 \%$ stearic acid as milling agent to avoid excessive welding of particles during milling.

Consolidation of the milled powders was carried out under a specific pressure of $400 \mathrm{MPa}$ at an automatic cold press. In order to produce high density electrical contacts, the green cylindrical compacts were HIP-ed using a press of AIP6-30H type at $1300 \pm 10^{\circ} \mathrm{C}$ and $1.5 \mathrm{~h}$ maintaining time at $190 \mathrm{MPa}$. To further increase the compactity degree, a calibration process with a press at 18 ton force on a specimen surface of $3.299 \mathrm{~cm}^{2}$, so 5.46 tf $/ \mathrm{cm}^{2}$ was applied.

Specimens sampled from HIP-ed electrical contacts were characterized from physical, microstructural, mechanical, and functional point of view.

The $\mathrm{W}-\mathrm{Cu}-\mathrm{Ni}$ particle size and polydispersity were measured in an aqueous suspension at $25^{\circ} \mathrm{C}$ and a scattering angle of $90^{\circ}$ by the dynamic light scattering (DLS) method with a 90 Plus particle size analyzer. Also, the crystalline phases formed in the MA-ed powder composites were analyzed by X-ray diffraction (XRD) technique by using a Bruker-AXS D8 Difractometer with $\mathrm{Cu} K_{\alpha}$ radiation.

The density of the contact materials was determined at $24{ }^{\circ} \mathrm{C}$ with a hydrostatic balance by the immersion technique using ethyl alcohol as a displaceable liquid.

The Vickers hardness values of the obtained electrical contacts were determined at room temperature (RT) by using a microdurimeter with an impression load of $2.942 \mathrm{~N}$ and a dwell time of $15 \mathrm{~s}$, while the metallographic analysis was performed with an optical microscope on polished and un-etched samples.

As shown in Fig. 5, pairs of two $\mathrm{W}-\mathrm{Cu}-\mathrm{Ni}$ electrical contacts pieces from each material composition fixed on copper supports were subjected to functional tests in order to determine the chopping current values.

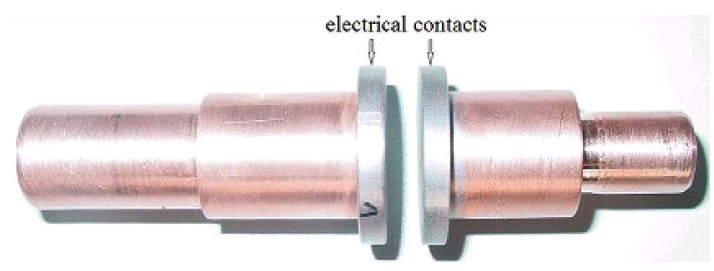

Fig. 5. W-Cu-Ni electrical contacts prepared for functional tests.

These measurements were performed on specific equipment realized by Icpe SA and UPB which consists of a vacuum unit containing a turbomolecular pump, a dipstick for pressure measuring, an ion pump, and an electric drive cabinet. The wave form of the injected current was acquired with a coaxial shunt and a Tektronix TDS 5034B oscilloscope. The chopping current tests on the obtained $\mathrm{W}-\mathrm{Cu}-\mathrm{Ni}$ electrical contacts were performed in 
the following conditions: pressure in the vacuum chamber of $10^{-5}$ mbar, injected current of $25-30 \mathrm{~A}$, opening velocity of electrical contacts of $1.5 \mathrm{~m} / \mathrm{s}$. The total number of measurements for each pair of specimens was 31 .

\section{Results and discussions}

Figure 6 shows the XRD patterns of the mechanical alloyed powder composites at various MA times $(10 \mathrm{~h}$ and $20 \mathrm{~h}$ ).

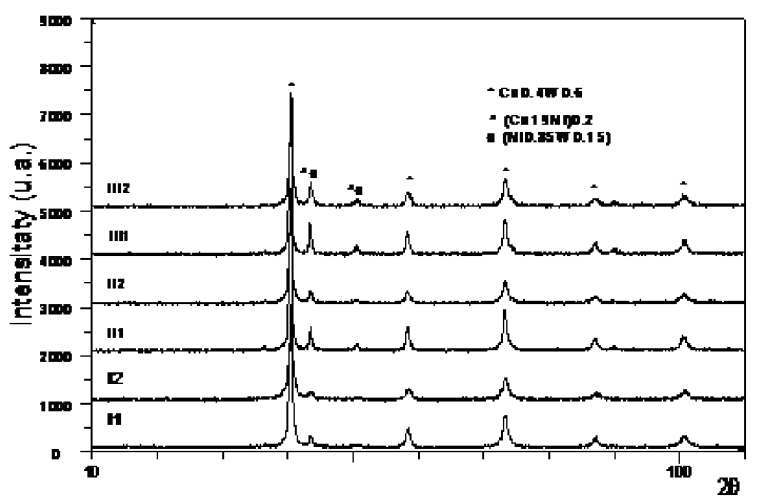

Fig. 6. X-ray diffraction patterns of mechanically milled powder composites.

Crystalline phases formed in the MA-ed composite such as $\mathrm{Cu}_{0.4} \mathrm{~W}_{0.6},\left(\mathrm{Cu}_{19} \mathrm{Ni}\right)_{0.2}$, and $\mathrm{Ni}_{0.85} \mathrm{~W}_{0.15}$ were found. As it can be observed from Fig. 6, for the highest MA time $(20 \mathrm{~h})$, the peaks corresponding to the $\mathrm{Cu}_{0.4} \mathrm{~W}_{0.6}$ metallic compound decrease in intensity which means a reduction in crystallite size. Also, with $\mathrm{Cu}$ content increasing from 20 to $40 \mathrm{wt} \%$, the intensity of the peak corresponding to the $\left(\mathrm{Cu}_{19} \mathrm{Ni}\right)_{0.2}$ is increasing.

Table I shows the average crystallite size of the main compound $\left(\mathrm{Cu}_{0.4} \mathrm{~W}_{0.6}\right)$ in the $\mathrm{W}-\mathrm{Cu}-\mathrm{Ni}$ mechanical alloyed powder composites. This compound is preferentially oriented on [110] direction for all the analyzed specimens.

It can be stated from Table I that an increase in the milling time from 10 to $20 \mathrm{~h}$ results in crystallite refinement for all the analyzed powder composites.

Table II shows the fine and coarse nanoparticle size distribution with a mean nanoparticle diameter and the polydispersity index obtained by DLS method for $\mathrm{W}-\mathrm{Cu}-\mathrm{Ni}$ powder mixtures.

From Table II, the mean diameter decreases both with $\mathrm{Cu}$ content increasing and milling time. The predominant finest particle size ranges have been registered for the powder composites $\mathrm{W}-30 \mathrm{Cu}-1 \mathrm{Ni}$ and $\mathrm{W}-40 \mathrm{Cu}-1 \mathrm{Ni}$ at the longest milling time $(20 \mathrm{~h})$. Also these nanopowders have shown a good polydispersity, since the polydispersity index is a measure of the distribution width. The more polydispersity index values are smaller the nanoparticle size distribution is more homogeneous.

Figure 7 shows some of the optical micrographs of the $\mathrm{W}-\mathrm{Cu}-\mathrm{Ni}$ electrical contact materials obtained by HIP technology.

The samples have shown homogeneous microstructures with visible $\mathrm{Cu}$ network distribution and some degree of porosity.

The average crystallite size of $\mathrm{Cu}_{0.4} \mathrm{~W}_{0.6}$ metallic compound.

\begin{tabular}{|c|c|c|c|c|}
\hline $\begin{array}{l}\text { Specimen } \\
\text { code }\end{array}$ & $\begin{array}{c}\text { Specimen composition } \\
\text { and mechanical } \\
\text { alloyed time } \\
\end{array}$ & $\begin{array}{c}\text { Crystallite size of } \\
\mathrm{Cu}_{0.4} \mathrm{~W}_{0.6}[\mathrm{~nm}] \\
{[110][200][211]}\end{array}$ & $\begin{array}{c}\text { Elementary cell } \\
\text { parameters of } \mathrm{Cu}_{0.4} \mathrm{~W}_{0.6} \\
a=b=c[\mathrm{~nm}]\end{array}$ & $\begin{array}{l}\text { Sheet of } \mathrm{Cu}_{0.4} \mathrm{~W}_{0.6} \\
\text { No. } 00-050-1451 \\
\text { cube }(a=b=c) \\
\end{array}$ \\
\hline I.1 & $\mathrm{W}-20 \mathrm{Cu}-1 \mathrm{Ni}(10 \mathrm{~h} \mathrm{MA})$ & 17.6815 .3412 .98 & 0.3159 & \multirow{6}{*}{0.3162} \\
\hline I. 2 & $\mathrm{~W}-20 \mathrm{Cu}-1 \mathrm{Ni}(20 \mathrm{~h} \mathrm{MA})$ & 15.5610 .5411 .82 & 0.3156 & \\
\hline II.1 & $\mathrm{W}-30 \mathrm{Cu}-1 \mathrm{Ni}(10 \mathrm{~h} \mathrm{MA})$ & 21.5217 .2418 .06 & 0.3165 & \\
\hline II. 2 & $\mathrm{~W}-30 \mathrm{Cu}-1 \mathrm{Ni}(20 \mathrm{~h} \mathrm{MA})$ & 16.6612 .6311 .76 & 0.3163 & \\
\hline III.1 & $\mathrm{W}-40 \mathrm{Cu}-1 \mathrm{Ni}(10 \mathrm{~h} \mathrm{MA})$ & 22.3320 .3416 .81 & 0.3165 & \\
\hline III. 2 & $\mathrm{~W}-40 \mathrm{Cu}-1 \mathrm{Ni}(20 \mathrm{~h} \mathrm{MA})$ & 19.2414 .1314 .76 & 0.3157 & \\
\hline
\end{tabular}

TABLE II

The nanoparticle size distribution and polydispersity index of the $\mathrm{W}-\mathrm{Cu}-\mathrm{Ni}$ powder composites.

\begin{tabular}{c|c|c|c|c}
\hline \hline $\begin{array}{c}\text { Specimen } \\
\text { code }\end{array}$ & $\begin{array}{c}\text { Mean } \\
\text { diameter [nm] }\end{array}$ & $\begin{array}{c}\text { Polydispersity } \\
\text { index }\end{array}$ & $\begin{array}{c}\text { Fine particles } \\
\text { size range [nm] }\end{array}$ & $\begin{array}{c}\text { Coarse particles } \\
\text { size range [nm] }\end{array}$ \\
\hline I.1 & $1316.2 \pm 81.7$ & $0.323 \pm 0.043$ & $175.73-231.91$ & $1224.95-1944.91$ \\
I.2 & $926.7 \pm 103.4$ & $0.321 \pm 0.073$ & $49.16-63.8$ & $666.31-1278.49$ \\
II.1 & $1252.5 \pm 63$ & $0.364 \pm 0.021$ & $115.06-179.28$ & $1056.78-1839.69$ \\
II.2 & $890.9 \pm 77.3$ & $0.262 \pm 0.037$ & $149.33-210.47$ & $762.12-1170.32$ \\
III.1 & $1043.6 \pm 73.6$ & $0.269 \pm 0.105$ & $358.35-514.01$ & $1516.81-2175.63$ \\
III.2 & $877.5 \pm 112.1$ & $0.275 \pm 0.133$ & $120.18-158.03$ & $745.78-1177.09$
\end{tabular}


TABLE III

Physical, mechanical and functional properties of the HIP-ed and calibrated $\mathrm{W}-\mathrm{Cu}-\mathrm{Ni}$ electrical contact materials.

\begin{tabular}{c|c|c|c|c|c|c}
\hline \hline $\begin{array}{c}\text { Specimen } \\
\text { code }\end{array}$ & $\begin{array}{c}\text { Electrical contact } \\
\text { material/MA time }\end{array}$ & $\begin{array}{c}\text { Theoretical } \\
\left.\text { density [g/cm }{ }^{3}\right]\end{array}$ & $\begin{array}{c}\text { Relative } \\
\text { density [\%] }\end{array}$ & $\begin{array}{c}\text { Vickers hardness } \\
\text { HV }_{0.3 / 15}\end{array}$ & \multicolumn{2}{|c}{ Chopping current [A] } \\
\cline { 5 - 7 } & Average & Maximum \\
\hline I.1 & W-20Cu-1Ni (10 h MA) & 15.5080 & 80.17 & $200.34 \pm 17$ & 2.52 & 3.92 \\
I.2 & W-20Cu-1Ni (20 h MA) & 15.5080 & 79.44 & $355.10 \pm 10$ & 2.55 & 4.85 \\
II.1 & W-30Cu-1Ni (10 h MA) & 14.1947 & 83.68 & $225.58 \pm 15$ & 2.09 & 4.34 \\
II.2 & W-30Cu-1Ni (20 h MA) & 14.1947 & 79.04 & $340.04 \pm 17$ & 3.14 & 5.12 \\
III.1 & W-40Cu-1Ni (10 h MA) & 13.0865 & 88.70 & $284.94 \pm 15$ & 3.70 & 5.96 \\
III.2 & W-40Cu-1Ni (20 h MA) & 13.0865 & 81.90 & $254.18 \pm 10$ & 3.82 & 8.58
\end{tabular}

Table III presents the physical, mechanical and functional properties of the HIP-ed and calibrated $\mathrm{W}-\mathrm{Cu}-\mathrm{Ni}$ electrical contact materials.

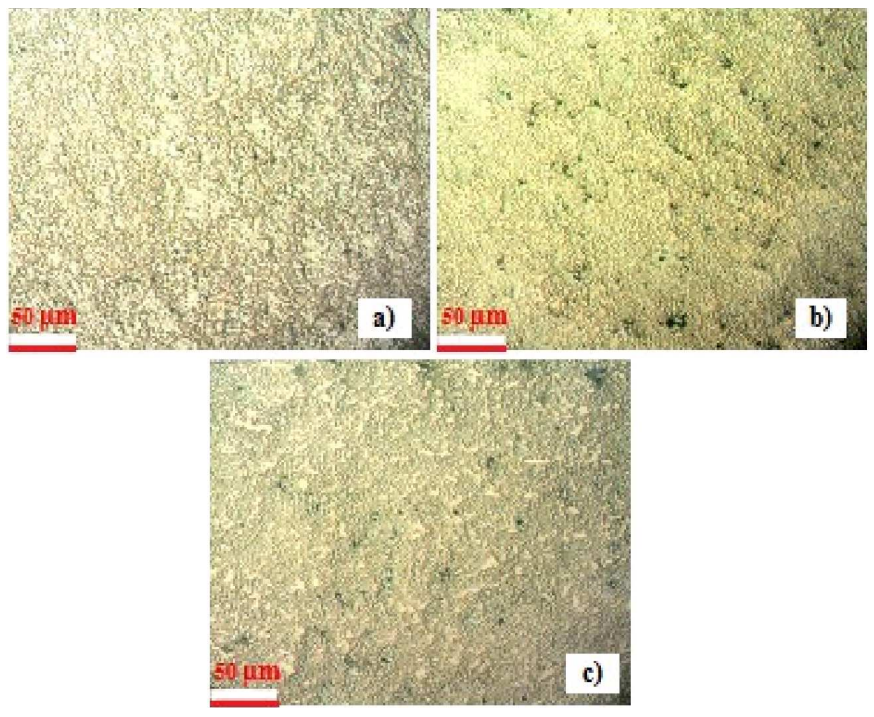

Fig. 7. Optical microscopy images for HIP-ed specimens: I.2 (a), II.1 (b) and III.2 (c), 300×, un-etched states.

From the data presented in Table III, all specimens have a degree of porosity, the minimum being $11.3 \%$ and the maximum $20.96 \%$, as it was shown from the optical micrographs (Fig. 7). The highest degree of compactity $(88.70 \%)$ had been obtained for the $\mathrm{W}-\mathrm{Cu}-\mathrm{Ni}$ electrical contact materials with the highest content of copper due to the uniform distribution of the liquid phase of copper. However, regarding the mechanical values, the highest values of the Vickers hardness had been obtained for the specimens with low content of copper, $20 \%$ and $30 \%$ respectively, and for the longest milling time $(20 \mathrm{~h})$. This is a consequence of increase of the fineness degree, the existence of a uniform distribution of the intermetallic phases $\left(\mathrm{Cu}_{0.4} \mathrm{~W}_{0.6},\left(\mathrm{Cu}_{19} \mathrm{Ni}\right)_{0.2}, \mathrm{Ni}_{0.85} \mathrm{~W}_{0.15}\right)$ into matrix and also, of the presence of the $\mathrm{W}$ majority harder phase.

An important parameter in the case of vacuum contactor is the chopping current value. This value is directly linked to the overvoltage produced in the commutation process. In the case of low voltage contactors, the chopping current value must be up to $5 \mathrm{~A}$ (peak value of the current - up to $50 \mathrm{~A}$ ). From Table III the lowest values for the chopping currents have resulted for the electrical contacts with a copper content lower than $40 \%$. This is explained by the fact that the average value of the chopping current decreases as the vapor pressure of the metal increases [13].

\section{Conclusions}

Nanostructured $\mathrm{W}-\mathrm{Cu}-\mathrm{Ni}$ electrical contact materials with $20-40 \mathrm{wt} \% \mathrm{Cu}$ and $1 \mathrm{wt} \% \mathrm{Ni}$ and balance wt\% $\mathrm{W}$ were obtained from MA-ed powders at $10 \mathrm{~h}$ and $20 \mathrm{~h}$ by hot isostatic press technology at $1300{ }^{\circ} \mathrm{C} \pm 10^{\circ} \mathrm{C}$, with a dwell time of $1.5 \mathrm{~h}$ at $190 \mathrm{MPa}$ and calibration at the at the specific pressure of $5.46 \mathrm{tf} / \mathrm{cm}^{2}$.

The highest degree of compactity $(88.70 \%)$ had been obtained for the $\mathrm{W}-\mathrm{Cu}-\mathrm{Ni}$ electrical contact materials with the highest content of copper (40\%) due to the uniform distribution of the liquid phase of copper into matrix.

The Vickers hardness values have increased for the $\mathrm{W}$ (20-30 wt\%) Cu-1 wt\% Ni electrical contact materials obtained at the longest milling time $(20 \mathrm{~h})$ due to increase of fineness degree, the existence of a uniform distribution of the intermetallic phases $\left(\mathrm{Cu}_{0.4} \mathrm{~W}_{0.6},\left(\mathrm{Cu}_{19} \mathrm{Ni}\right)_{0.2}\right.$, $\left.\mathrm{Ni}_{0.85} \mathrm{~W}_{0.15}\right)$ into matrix and, also, to the presence of $\mathrm{W}$ which is the majority and harder phase from the matrix.

The lowest values for the chopped currents and, consequently, low amplitude overvoltage which is very disadvantageous to the electric system, were obtained for the $\mathrm{W}-\mathrm{Cu}-\mathrm{Ni}$ electrical contact materials with relative density of about $80 \%$ and copper content lower than $40 \%$ such as: $\mathrm{W}-20 \mathrm{Cu}-1 \mathrm{Ni}(10 \mathrm{~h}$ of MA and $20 \mathrm{~h}$ of MA) and $\mathrm{W}-30 \% \mathrm{Cu}-\mathrm{Ni}(10 \mathrm{~h}$ of $\mathrm{MA})$.

For the highest content of ductile phase of $\mathrm{Cu}$ (40 wt\%), the shorter milling time $(10 \mathrm{~h})$ had a more positive effect on all physical, mechanical and functional properties.

\section{Acknowledgments}

The authors would like to gratefully acknowledge the Executive Unit for Financing Higher Education, Research, Development and Innovation (UEFISCDI) for 
funding the collaborative applied research project PN-II-PT-PCCA, contract no. 34/2012, acronym NeWaLC.

\section{References}

[1] H. Abbaszadeh, A. Masoudini, H. Safabinesh, M. Takestani, Int. J. Refract. Met. H 30, 145 (2012).

[2] J. Fan, T. Liu, S. Zho, Y. Han, Int. J. Refract. Met. $H$ 30, 33 (2012).

[3] A. Abu-Oqail, M. Ghanim, M. El-Sheikh, A. ElNikhaily, Int. J. Refract. Met. H 35, 207 (2012).

[4] S.H. Hong, B.K. Kim, Mater. Lett. 57, 2761 (2003).

[5] S.S. Ryu, Y.D. Kim, I.H. Moon, J. Alloys Comp. 335, 233 (2002).

[6] T.B. Massalski, H. Okamoto, P.R. Subramanian, L. Kacprzak, Binary Alloy Phase Diagrams, 2nd ed., Wiliam W. Scott Pub., New York 1990.

[7] D. Li, Z. Liu, Y. Yu, E. Wang, J. Alloys Comp. 462, 94 (2008).
[8] L.J. Kecskes, M.D. Trexler, B.R. Klotz, K.C. Cho, R.J. Dowding, Metal. Mater. Trans. A 32, 2885 (2001).

[9] T.S. Srivatsan, K. Manigandan, M. Petraroli, R.M. Trejo, T.S. Sudarshan, Adv. Powder Technol. 24, 190 (2013).

[10] H. Gökçe, Ö. Balci, D. Ağaoğullari, Ö.U. Demirkan, A. Genç, M.L. Öveçoğlu, İ. Duman, Acta Phys. Pol. A 123, 309 (2013).

[11] J.H. Ahn, H. Chung, Met. Mater.-Korea 5, 295 (1999).

[12] M. Roosta, H. Baharvandi, H. Abdizade, Int. J. Ind. Chem. 3, 1 (2012).

[13] S. Eroglu, T. Baykara, J. Mater. Proc. Tech. 103, 288 (2000). 